\title{
CORRIGENDA
}

\section{Corrigendum: The Practice of Geriatrics: Specialized Geriatric Programs and Home Visits}

David B. Hogan, MD, FRCPC, FACP

Department of Medicine, University of Calgary, Calgary, Alberta

DOI:http://dx.doi.org/10.5770/cgj.16.94

\section{Original Citation}

Can Geriatr J. 2011;14(1):17-23. Epub 2011 Apr 13.

\section{Author Description of the Error and Correction}

Three references are incorrectly numbered and are in the wrong order on page 22 . Reference \#7 should be re-numbered as \#10. Reference \#8 should be re-numbered as \#7. Finally, reference \#10 should be re-numbered as \#8. The rest of the references are correct (including \#9).

There is an error on page 17, left-hand column, 2nd paragraph from the top, and third sentence from the top:

"This dropped by $21.4 \%$ over the next five years."

The sentence should be changed to:

"This had dropped by $24.2 \%$ between 1981 and 1986."

\section{Corrected Reference List:}

1. Thewlis MW. In Memoriam: Nascher - Father of Geriatrics. Med Times 1945;73:140-41.

2. Howell T. Comment - Origins of the British Geriatrics Society. Age Ageing 1974;3:69-72.

3. Anonymous. Eric Barrington Brooke. Lancet 1957;272:221-22.

4. Arcand M, Williamson J. An evaluation of home visiting of patients by physicians in geriatric medicine. Brit Med $J$ 1981;283:718-20.

5. Brooke EB. The Place of the Out-Patient Department in Caring for Old People. Med Press 1948;219:400-2.

6. Lord Amulree, Exton-Smith AN, Crockett GS. Proper Use of the Hospital in Treatment of the Aged Sick. Lancet 1951;i:123-26.

7. Fry J, Sandler G. Domiciliary consultations: Some facts and questions. Brit Med J 1988;297:337-38.

8. Taylor IC, McConnell JG. Geriatric medicine: the anatomy of change. Ulster Med J 1994;63(2):162-69.

9. Lister J. The NHS after 60: For Patients or Profits? London, UK: Middlesex University Press; 2008:117.
10. Centre for the History of Medicine, BGS Scotland. Domiciliary Visiting by Geriatricians: The Good Old Days? A Witness Seminar in the History of Medicine. Glasgow, UK: Centre for the History of Medicine, Department of Economic and Social History, University of Glasgow (Glasgow); 2007.

11. Anonymous. House Calls and Home Visits. Lancet 1963;i:1409.

12. Meyer GS, Gibbons RV. House calls to the elderly - a vanishing practice among physicians. New Engl J Med 1997;337:1815-20.

13. Hobbs FD. Violence in general practice: a survey of general practitioners' views. BMJ 1991;302:329-32.

14. Mulley GP. Home visiting by consultants. BMJ 1988; 296:515-16.

15. Hardy-Thompson C, Orrell MW, Bergmann K. Evaluating a psychogeriatric domiciliary visit service: views of general practitioners. BMJ 1992;304:421-22.

16. Orrell MW, Hardy-Thompson C, Bergmann K. Comparison between general practitioners with high or low use of psychogeriatric domiciliary visit service. Int J Geriatr Psychiatry 1992;7:885-89.

17. Orrell M, Katona C. Do Consultant Home Visits Have a Future in Old Age Psychiatry? Int J Geriatr Psychiatry 1998;13:355-57.

18. Sutherby K, Srinath S, Strathdee G. The domiciliary consultation service: outdated anachronism or essential part of community psychiatric outreach? Health Trends 1992;24(3):103-5.

19. Donaldson LJ, Hill PM. The domiciliary consultation service: time to take stock. BMJ 1991;302:449-51.

20. Forsythe M. Domiciliary visits. BMJ 1991;302:426-27.

21. Reardon M, Holmon R, Dewhurst G. A survey of domiciliary consultations in medicine for the elderly. Public Health 1995;109:187-90.

22. Crome P, Malham A, Baker D, et al. Domiciliary visits to the old and the mentally ill: how valuable? J Roy Soc Med 2000;93:187-90.

23. Simpson S, Beavis D, Dyer J, et al. Should old age psychiatry develop memory clinics? A comparison with domiciliary work. Psychiatr Bull 2004;28:78-82.

24. Dennis M, Furness L, Lindesay J, et al. Assessment of patients with memory problems using a nurse-administered instrument to detect early dementia and dementia subtypes. Int $J$ Geriatr Psychiatry 1998;13:405-9. 
25. Seymour J, Saunders P, Wattis JP, et al. Evaluation of early dementia by a trained nurse. Int $J$ Geriatr Psychiatry 1994;9:37-42.

26. Galvin JE, Roe CM, Powlishta KK, et al. The AD8: A brief informant interview to detect dementia. Neurology 2005;65:559-64.

27. Trapp-Moen B, Tyrey M, Cook G, et al. In-Home Assessment of Dementia by Nurses: Experience Using the CERAD Evaluations. Gerontologist 2001;41:406-9.

28. Page $\mathrm{S}$, Hope $\mathrm{K}$, Bee $\mathrm{P}$, et al. Nurses making a diagnosis of dementia - a potential change in practice? Int J Geriatr Psychiatry 2008;23:27-33.

29. Ramsdell JW, Jackson JE, Guy HJB, et al. Comparison of Clinic-Based Home Assessments to a Home Visit in Demented Elderly Patients. Alzheimer Dis Assoc Disord 2004;18:145-53.

30. Ramsdell JW, Swart JA, Jackson JE, et al. The yield of a home visit in the assessment of geriatric patients. J Am Geriatr Soc 1989;37:17-24.

31. Shievitz AL, Tudiver F, Araujo A, et al. Do elderly people score better on cognitive tests at home? Can Fam Physician 1998;44:1652-56.

32. Ward HW, Ramsdell JW, Jackson JE, et al. Cognitive function testing in comprehensive geriatric assessment. A comparison of cognitive test performance in residential and clinic settings. J Am Geriatr Soc 1990;38:1088-92.

33. Di Monaco M, Vallero F, De Toma E, et al. A single home visit by an occupational therapist reduces the risk of falling after hip fracture in elderly women: a quasi-randomized controlled trial. J Rehabil Med 2008;40:446-50.

34. Cumming RG, Thomas M, Szonyi G, et al. Home visits by an occupational therapist for assessment and modification of environmental hazards: a randomized trial of falls prevention. J Am Geriatr Soc 1999;47:1397-402.

35. Gillespie LD, Robertson MC, Gillespie WJ, et al. Interventions for preventing falls in older people living in the community. Cochrane Database Syst Rev 2009;(2):CD007146.

36. Jackson JE, Ramsdell JW, Renvall M, et al. Reliability of Drug Histories in a Specialized Geriatric Outpatient Clinic. J Gen Intern Med 1989;4:39-43.

37. Yang JC, Tomlinson G, Naglie G. Medication Lists for Elderly Patients. J Gen Intern Med 2001;16:112-15.

38. Clarfield AM, Bergman H. Medical home care services for the housebound elderly. CMAJ 1991;144:40-45.

39. Tandeter H, Peleg R, Menahem S, et al. Teaching geriatric assessment in home visits: the family physician/geriatrician attachment. Teach Learn Med 2003;15:123-6.

40. Mitsis EM, Jacobs D, Luo X, et al. Evaluating cognition in an elderly cohort via telephone assessment. Int J Geriatr Psychiatry 2010;25:531-9.

41. Gaikwad R, Warren J. The role of home-based information and communications technology interventions in chronic disease management: a systematic literature review. Health Informatics J 2009; 15:122-146.

42. American Geriatrics Society Clinical Practice Committee. The Role of House Calls in Geriatric Practice. New York: The American Geriatrics Society; 2006.

43. Landers SH. Why Health Care Is Going Home. N Engl J Med 2010;363:1690-1.

44. Kao H, Conant R, Soriano T, et al. The Past, Present, and Future of House Calls. Clin Geriatr Med 2009;25:19-34. 